\author{
Ks. Miroslaw Lanoszka* \\ UPJPII w Krakowie Wydzial Teologiczny Sekcja w Tarnowie
}

\title{
STWORZENIE W ŚWIETLE BIBLII - NAKREŚLENIE ZASADNICZYCH WĄTKÓW
}

Biblijne wypowiedzi o stwórczym dziele Boga, posługując się starannie dobraną terminologią, zawierają pouczenia o charakterze teologicznym ${ }^{1}$. Pismo Święte otwiera Księga Rodzaju, której początkowe rozdziały mieszczą w sobie dwa obszerne opowiadania o stworzeniu świata i człowieka $(\operatorname{Rdz} 1-2)$. Pierwsze z nich to bardzo podniosły tekst pochodzący z tradycji kapłańskiej, który mówiąc o stworzeniu świata w ciągu siedmiu dni, wprowadza dwa główne podmioty historii zbawienia: Boga-Stwórcę oraz Jego stworzenie wchodzące z Nim w życiodajną relację (Rdz 1,1 - 2,4a). Drugie opowiadanie, wywodzące się z tradycji jahwistycznej, którego atmosfera bardziej przypomina mitologiczne kosmogonie, ukazuje, jak to Bóg ulepił człowieka z prochu ziemi (Rdz 2,4b-25). Chociaż przywołane teksty różnią się, to jednak głoszą jedną prawdę: świat został stworzony przez Boga, a więc wszystko, co istnieje, zawdzięcza Mu swoją egzystencję, a to oznacza, że każde stworzenie jest zależne od Niego. To jakże ważne teologiczne przesłanie wskazuje zatem na cel przekazanych w Księdze Rodzaju dwóch różnych opowiadań o stworzeniu, którym nie jest bynajmniej chronologiczny opis przebiegu wydarzeń związanych z powoływaniem do istnienia świata i człowieka, ale odsłonięcie sensu dokonanego przez Boga dzieła. Stąd też w tych biblijnych przekazach należy szukać głębokiej prawdy religijnej, która została wyrażona $\mathrm{w}$ niezwykle dynamicznych i poetyckich obrazach mówiących o Bogu, o dokonanym przez Niego stworzeniu, a zwłaszcza o miejscu człowieka w Jego dziele. Literacka struktura tych biblijnych poematów charakteryzuje się polifonią, która pozwala usłyszeć głosy różnych

* Ks. Mirosław Łanoszka, doktor nauk teologicznych w zakresie biblistyki, asystent przy Katedrze Egzegezy Starego Testamentu na Wydziale Teologicznym Sekcja w Tarnowie UPJPII w Krakowie, członek Stowarzyszenia Biblistów Polskich, współpracownik Dzieła Biblijnego im. Jana Pawła II w Diecezji Tarnowskiej, wykładowca w Radiowo-Internetowym Studium Biblijnym prowadzący wykłady z egzegezy ksiąg Starego Testamentu oraz biblijnego języka hebrajskiego.

Por. G. von Rad, Teologia Starego Testamentu, tłum. B. Widła, Warszawa 1986, s. $118-119$. 
autorów opowiadających o trudnej do uchwycenia rzeczywistości Boga i człowieka ${ }^{2}$.

Zgodnie z powyższym trzeba wyraźnie zaznaczyć, że zamieszczone w Księdze Rodzaju opowiadania o powstaniu świata i pojawieniu się człowieka nie są naukowym zapisem przebiegu przyrodniczych procesów, które miały miejsce $\mathrm{w}$ odległej przeszłości, a zatem zawartej w nich prawdy nie można mierzyć przy pomocy analiz właściwych fizyce czy biologii. Stąd też pozbawione są podstaw wszelkie usiłowania uzgodnienia dosłownie odczytywanego biblijnego opowiadania o stworzeniu świata (lektura fundamentalistyczna Pisma Świętego) z najnowszymi naukowymi teoriami lub zniekształcenia ich w taki sposób, by odpowiadały zamierzonej z góry interpretacji natchnionego tekstu. Tymczasem wspomniane biblijne opowiadania nie zajmują się przyrodniczymi analizami powstania świata i człowieka, ale uroczyście oznajmiają religijną prawdę o wszechmocnym i mądrym Bogu, który stworzył pojmowalny wszechświat, nadał mu głęboki sens, usprawiedliwiając tym samym naukowe podejście do natury ${ }^{3}$.

Warto $\mathrm{w}$ tym miejscu przytoczyć wypowiedź pochodzącą $\mathrm{z}$ dokumentu Papieskiej Komisji Biblijnej na temat „Interpretacji Biblii w Kościele”, odrzucającą fundamentalistyczną lekturę Pisma Świętego, która „nieświadomie myli ludzkie ograniczenia biblijnego orędzia z Boską treścią tegoż orędzia"4: „Lektura fundamentalistyczna wychodzi z założenia, że Biblia, będąc natchnionym słowem Bożym, powinna być czytana i interpretowana dosłownie we wszystkich szczegółach. Podstawowym problemem lektury fundamentalistycznej jest to, że odrzucając historyczny charakter biblijnego objawienia, nie potrafi w pełni przyjąć prawdy o wcieleniu. Nie chce przyjąć, że natchnione słowo Boże zostało wyrażone ludzkim językiem i zostało zredagowane pod Bożym natchnieniem przez ludzkich autorów, których zdolności i środki były ograniczone" 5 .

Przykładem teologicznie krytycznego podejścia w interpretacji pierwszych rozdziałów Księgi Rodzaju, które nie ignorowało naukowych odkryć swojego czasu mogą być dokonania żyjącego na przełomie XIX i XX stulecia angielskiego biblisty S.R. Drivera (1846-1914). Uczony ten, komentując początkowe teksty Księgi Rodzaju, zwrócił uwagę na zewnętrzny i wewnętrzny sens znajdujących się tam opowiadań. Zgodnie z jego propozycją zewnętrzny sens biblijnych przekazów, który został wyrażony przy pomocy idei i terminów właściwych dla środowiska kulturowego starożytnego Bliskiego Wschodu, posiada narratywną formę (opowiadanie), natomiast wewnętrzny sens tych

${ }^{2}$ Por. J. L'Hour, Genèse 1-11. Les pas de l'humanité sur la terre, „Cahiers Évangile” 161(2012), s. 3.

${ }^{3}$ Por. G. J. Wenham, Genesis 1-15, „Word Biblical Commentary” 1, Dallas 1987, s. 40.

${ }^{4}$ Interpretacja Biblii w Kościele. Dokument Papieskiej Komisji Biblijnej z komentarzem biblistów polskich, thum. i red. R. Rubinkiewicz SDB, Warszawa 1999, s. 57.

${ }^{5}$ Tamże, s. 54-55. 
fragmentów determinuje zawarta $\mathrm{w}$ nich objawiona prawda, której istoty w żaden sposób nie narusza krytyczna analiza biblijnego tekstu ${ }^{6}$.

Pamiętając, że celem biblijnych opowiadań o stworzeniu świata i człowieka jest ukazanie sensu stwórczego dzieła Boga, warto zwrócić uwagę na istotne elementy tych tekstów, które posiadają fundamentalne znaczenie dla historii zbawienia, gdyż odsłaniają tożsamość człowieka, naturę świata, a nade wszystko mówią o Bogu, który wszystko stwarza i błogosławi to, co stworzył. Opowiadanie o stworzeniu zamieszczone w pierwszym rozdziale Księgi Rodzaju (dokładnie: Rdz 1,1 - 2,4a), którego literacką strukturę wyznacza schemat siedmiu dni, a precyzyjnie - sześć dni tygodnia stwórczego oraz siódmy dzień odpoczynku, czyli szabat, opiera się na kilku powtarzalnych pojęciach ${ }^{7}$.

Absolutny charakter stworzenia wyraża hebrajski termin $b \bar{a} r \bar{a}$ ' (,stwarzać") używany w Starym Testamencie wyłącznie w odniesieniu do wolnego stwórczego działania, którego podmiotem jest Bóg, powołujący wszystko do istnienia i niepotrzebujący przy tym niczego, by urzeczywistnić swoją wolę. $\mathrm{Z}$ treścią przywołanego czasownika wiąże się sformułowanie otwierające pierwsze opowiadanie o stwórczym dziele Boga, a tym samym całą Biblię: „Na początku Bóg stworzyl” (Rdz 1,1). Fraza „na początku” (hebr. brée'sît) pozwala myśleć o początku absolutnym, a więc o takim, którego nic nie poprzedza ${ }^{8}$. W ten sposób można mówić o czymś, co nie jest związane z czasem, wyrazić ideę rzeczywistości, która znajduje się u samych korzeni, u podstaw istnienia świata i człowieka. Utrwalone na początku Księgi Rodzaju sformułowanie, które rozpoczyna opowiadanie o stworzeniu, stanowi pierwsze przekazane w Biblii wyznanie wiary. Stąd też trzeba wyraźnie powiedzieć, że stwierdzenie „Na początku Bóg stworzył niebo i ziemię” (Rdz 1,1), stanowiące element chrześcijańskiego wyznania wiary („Wierzę w jednego Boga, Stworzyciela nieba i ziemi”) nie ma charakteru naukowego, ale mieści w sobie głęboki sens religijny - oznacza, że Bóg, stwarzając świat, odsłonił siebie oraz dał poznać swoją wolę. Przytoczone słowa wyznania wiary w Stwórcę nieba i ziemi mówią o całym wszechświecie jako darze Boga, który nie potrzebując niczego, powołał do istnienia wszystkie byty, sprawiając absolutnie nowy początek, obejmujący teraźniejszość, przeszłość i przyszłość ${ }^{9}$.

Inna, powtarzająca się dziesięciokrotnie w tym tekście formuła: „Bóg rzekł" (hebr. wajjō'mer 'élohîm), mówi o tym, że słowo Boga jest kreatywne i skuteczne, gdyż wypowiedziane sprawia zaistnienie tego, co wyraża. Warto wspomnieć przynajmniej jeszcze jedną frazę o charakterze konstytutywnym

\footnotetext{
${ }^{6}$ Por. J.W. Rogerson, Genesis 1-11, w: J.W. Rogerson, R.W.L. Moberly, W. Johnstone, Genesis and Exodus, Sheffield 2001, s. 37.

${ }^{7}$ Por. P. Beauchamp, Création et séparation. Étude exégétique du chapitre premier de la Genèse, Paris 2010, s. 28.

${ }^{8}$ Por. G. J. Wenham, Genesis $1-15$, dz. cyt., s. 14.

${ }^{9}$ Por. B. Costacurta, Obietnica życia w Księdze Rodzaju, tłum. D. Piekarz, Kraków 2005, s. 24.
} 
dla teologicznej warstwy wersetów opowiadających o stworzeniu. Sformułowanie ukazujące Boga, który „oddzielił” (hebr. wajjabudēl 'ělohîm) jedne rzeczy od drugich, by jako różne od siebie mogły istnieć, należy bez wątpienia do centralnych idei pierwszego rozdziału Księgi Rodzaju. Bóg, który nie jest zmuszony do stwarzania, zaprzestaje swojej stwórczej aktywności dopiero wtedy, kiedy wszystko zostało dokonane, co znajduje swój wyraz w stwierdzeniu, że całe stworzenie powołane przez Boga do istnienia jest „,bardzo dobre" (hebr. $t \hat{o} \underline{b} m^{e}$ 'od). Biblijne opowiadanie o stworzeniu (Rdz 1) ukazuje zatem wolnego i transcendentnego Boga, którego stwórcze dzieło jest wynikiem Jego bezinteresownego działania. Stąd też ukończenie dzieła stworzenia wieńczy radosna proklamacja mówiąca o tym, że to, co zostało powołane do istnienia, jest dobre, a odpoczynek szabatu staje się czasem umożliwiającym wielbienie Boga-Stwórcy pośród rozradowanego stworzenia. Pobłogosławienie i uświęcenie przez Boga dnia siódmego czyni z niego szabat, a więc poprzedzony sześcioma dniami pracy moment, w którym człowiek powinien odpowiadać Bogu na dar dokonanego przez Niego stworzenia ${ }^{10}$.

Ważnym fragmentem dla teologii opowiadania o stworzeniu przekazanego w pierwszym rozdziale Księgi Rodzaju - będącym jednocześnie dobrym przykładem, że tekst ten nie odtwarza chronologii stwarzania poszczególnych bytów, ale służy ukazaniu sensu Bożego słowa - jest powołanie do istnienia ciał niebieskich, które następuje dopiero czwartego dnia (por. Rdz 1,14-19). Obecna w tekście biblijnym niezgodność chronologiczna dotycząca pojawienia się światłości jako skutku następstwa dnia i nocy, co ma miejsce już pierwszego dnia (por. Rdz 1,3-5), a powstaniem nieodzownych dla uzyskania tej podstawowej przemienności jasności i ciemności ciał niebieskich (słońca, księżyca i gwiazd), co ma miejsce dnia czwartego (por. Rdz 1,14-19), stanowi ostrzeżenie, żeby nie traktować tych opisów jako kroniki stworzenia, ale wydobywać $\mathrm{z}$ nich prawdziwe znaczenie. Biblijny narrator nie zamierzał bowiem przedstawiać naukowych wyjaśnień na temat genezy i funkcjonowania ciał niebieskich. Pragnął przede wszystkim powiedzieć, że świecące obiekty, które mają służyć człowiekowi w określaniu czasu, nie posiadają statusu bóstwa, a wręcz można powiedzieć, że w tym opowiadaniu zostały go pozbawione. $\mathrm{W}$ przeciwieństwie do egipskich i babilońskich kultów astralnych, słońce i księżyc w tekstach biblijnych są narzędziami, którym Bóg przydzielił pewne funkcje, dzięki czemu człowiek otrzymał dar czasu, jednak nie może nim zarządzać tak jak światem, bo ten czas należy do Boga ${ }^{11}$.

Zgłębiając sens opowiadań o stwórczym dziele Boga, przekazanych w pierwszych dwóch rozdziałach Księgi Rodzaju, trzeba pamiętać, że wszystko, co Bóg uczynił, zostało stworzone dla człowieka, który ma łączyć w sobie dwa wymiary: ziemski i nadprzyrodzony. Jest bowiem obrazem Boga, uczynionym na Jego podobieństwo w przeddzień szabatu, a więc także i szczytem Jego stwórczego działania, ale jednocześnie został powołany

\footnotetext{
${ }^{10}$ Por. J. L'Hour, Genèse 1-11, dz. cyt., s. 16-17.

${ }^{11}$ Por. G. J. Wenham, Genesis 1-15, dz. cyt., s. 21-22.
} 
do istnienia w tym samym dniu, co zwierzęta, otrzymując ten sam pokarm oraz to samo błogosławieństwo (por. Rdz 1,26-29). Aby człowiek mógł obronić się przed fałszywą pokusą prowadzącą bądź do uważania się za Boga, bądź - ignorując fakt, że został stworzony na Boży obraz i podobieństwo - redukowania się do poziomu zwierzęcia, trzeba zawsze łączyć te dwa wymiary. Człowiek ma być bowiem obrazem Boga, pamiętając o wdzięczności i uwielbieniu Stwórcy za ten dar, i jednocześnie nie zapominając o swoim związku ze światem zwierzą ${ }^{12}$.

Obszerne opowiadania o stworzeniu świata i człowieka, jakie zostały zawarte w pierwszym i drugim rozdziale Księgi Rodzaju mówią zgodnie, chociaż w różny sposób, że wszystko, co istnieje, zostało stworzone przez Boga, należy do Niego i było przez Niego chciane. Umieszczone na początku Biblii teksty kładą podwaliny pod to, co zostanie powiedziane dalej w dziejach zbawienia. Objawiają bowiem, kim jest człowiek, czym jest świat, a nade wszystko - kim jest wszechmocny i mądry Bóg, będący źródłem dobroci stworzenia. A zatem można powiedzieć, że obydwa opowiadania o stwórczym dziele Boga afirmują dobroć zamierzonego przez Niego stworzenia ${ }^{13}$.

Tematyka dotycząca stwórczego dzieła Boga obecna jest także w wielu psalmach, które nie tyle podają teologiczną naukę o stworzeniu świata i człowieka, ile koncentrują swoją myśl na wysławianiu Stwórcy za dokonane przez Niego dzieła ${ }^{14}$. Bóg bowiem poprzez swoje cudowne dzieła, mające fundamentalne znaczenie dla ludzkiego zbawienia, objawił się i pozwolił się poznać człowiekowi, który pragnie utrwalić to zbawcze działanie w liturgicznych celebracjach (por. Ps 111,4$)^{15}$. Stąd też Stary Testament świadczy o tym, że Bóg objawił siebie i swoją wolę przede wszystkim poprzez swoje dzieło stworzenia. Przekonanie to znalazło swój wyraz w słowach psalmisty: „Niebo ogłasza chwałę Boga, firmament obwieszcza dzieło rąk Jego. Dzień dniowi przekazuje słowo, noc nocy oznajmia naukę" (Ps 19,2-3). Użyte w hebrajskim tekście przytoczonego fragmentu formy gramatyczne czasowników (imiesłowy) sugerują trwały charakter Bożego objawienia, a zatem wysławianie chwały Boga odbywa się nieustannie ${ }^{16}$. Podobną konstatację na temat świadectwa dzieł stwórczych, które wskazują na swojego Sprawcę, można znaleźć w Psalmie 8, gdzie budzące zachwyt niebieskie ciała świecące zostały ukazane jako „dzieła Bożych palców”: „Gdy patrzę na niebo, dzieło Twoich palców, księżyc i gwiazdy, które utwierdziłeś...” (Ps 8,4). To wszystko, co człowiek podziwia, skłania go do wychwalania Stwórcy, gdyż sam zdaje sobie sprawę, że piękno stworzonego świata jest jednocze-

\footnotetext{
${ }^{12}$ Por. B. Costacurta, Obietnica, dz. cyt., s. 24-25.

${ }^{13}$ Por. W. Brueggemann, An introduction to the Old Testament. The canon and Christian imagination, Louisville (Kentucky) - London 2003, s. 31-32.

${ }^{14}$ Por. G. von Rad, Teologia Starego Testamentu, dz. cyt., s. 119.

${ }^{15}$ Por. H.-J. Kraus, Psalms 60-150. A Continental commentary (translated from the German by H.C. Oswald), Minneapolis 1993, s. 358.

${ }^{16}$ Por. J.-L. Vesco, Le Psautier de David. Traduit et commenté, t. I, Paris 2008,
} s. 206-207. 
śnie świadectwem blasku chwały Bożego miłosierdzia wobec stworzenia: „Czym jest człowiek, że o nim pamiętasz, i czym śmiertelnik, że troszczysz się o niego?" (Ps 8,5). Przedstawiony w psalmach świat, jako stwórcze dzieło Boga (por. Ps 104; 124,8; 145,5; 146,6), opowiada równocześnie o Bożych przymiotach, takich jak wszechmoc (por. Ps 74,12-17; 89,6-16), mądrość (por. Ps 104,24), dobroć (por. Ps 65,10-14) i wierność (por. Ps 56,6; $119,8-9$ ). Boże dzieło stworzenia wzbudza podziw człowieka dla wielkości Stwórcy (por. Ps $8,5-7 ; 65,6-9$ ), a także skłania go, by obdarzył dobrego Boga bezgranicznym zaufaniem (por. Ps $55,11.21 ; 75,26-28)^{17}$.

W tekstach Deutero-Izajasza (Iz 40 - 55) tematyka stworzenia zbiega się z ze zbawczym działaniem Boga, stąd też prorocy głosili wszechmoc Stwórcy i Jego potęgę uobecniającą się $\mathrm{w}$ historii zbawienia ${ }^{18}$. DeuteroIzajasz, świadcząc o absolutnej suwerenności Boga, oznajmia Jego słowa: „Aby poznano od wschodu aż po zachód, że oprócz Mnie nie ma nikogo! Ja jestem Panem i nie ma nikogo. Ja stwarzam światłość i tworzę ciemność, obdarzam szczęściem i zsyłam niedolę" (Iz 45,6-7). Sam powrót do Jerozolimy z wygnania babilońskiego został opisany z wykorzystaniem hebrajskiego terminu $b \bar{a} r \bar{a}$ ' (,stwarzać”), widzianego jako czyn stwarzający, który odnosi się zarówno do pierwotnego stworzenia świata i człowieka (por. Iz 40,26.28; 43,1-7; 45,7.12.18), jak i do chwili obecnej (por. Iz 54,16), a także do mającej dopiero nadejść pełni zbawczej (por. Iz 41,20; 42,5-8), gdyż Bóg, który stworzył wszechświat, jest jednocześnie Stwórcą wszystkich ludzi, a to oznacza, że tylko On może zbawić i wyzwolić każdego (por. Iz 40,27-31) ${ }^{19}$.

Tematyka dotycząca stworzenia, która nie zajmowała zbyt wiele miejsca w biblijnych tekstach sprzed deportacji babilońskiej (VI wiek przed Chr.) ${ }^{20}$, nabrała nowego znaczenia teologicznego $\mathrm{w}$ momentach narodowych dramatów, jakich doświadczyli Izraelici w związku z agresją Asyrii (VIII wiek przed Chr.) i Babilonii (VI wiek przed Chr.), co skutkowało przesiedleniami znacznej części populacji Izraela na obszar Mezopotamii, zajmowany sukcesywnie przez wymienione starożytne imperia. To właśnie upokarzająca sytuacja żydowskich wygnańców w Babilonii sprawiła, że wyznawana przez nich wiara nie uległa stagnacji, ale paradoksalnie doświadczenia niewoli stały się decydującym momentem w jej rozwoju ${ }^{21}$. Przeżywany w czasie wygnania dramat, który doprowadził społeczność narodu wybranego do kryzysu wiary, jednocześnie pozwolił odkryć jej nowy wymiar, gdyż dopiero wtedy, kiedy wszystko zostało utracone, uświadomiono sobie, że Bóg jest Stwórcą wszechrzeczy „Stworzycielem nieba i ziemi”, a wiara Izraela w Niego jest prawdą. Starotestamentowe świadectwa o stworzeniu wskazującym na odwiecznie istniejące-

${ }^{17}$ Por. P. Auvray, Stworzenie, w: Stownik teologii biblijnej, red. X. Léon-Dufour, Poznań - Warszawa 1982, s. 911.

${ }^{18}$ Por. G. von Rad, Teologia Starego Testamentu, dz. cyt., s. 117.

${ }^{19}$ Por. R. N. Whybray, The Second Isaiah, New York 2003, s. 53-57.

${ }^{20}$ Por. G. von Rad, Teologia Starego Testamentu, dz. cyt., s. 116.

${ }^{21}$ Por. R. N. Whybray, The Second Isaiah, New York 2003, s. 16. 
go jedynego Boga, które w swoim przekazie nabrały na skutek narodowych dramatów Izraela nowych cech, można odnaleźć w takich tekstach, jak pierwszy rozdział Księgi Rodzaju, fragmenty dotyczące stworzenia u DeuteroIzajasza, czy też biblijna literatura mądrościowa (np. Prz 8; Syr 24$)^{22}$.

Temat tajemnicy stworzenia podejmuje w specyficzny sposób autor Księgi Hioba, prezentując go w ramach pierwszej mowy Boga do Hioba (Hi $38-40$ ). W tekście tym Bóg pyta Hioba o to, gdzie był, kiedy On kładł fundamenty tego świata, zgodnie $\mathrm{z}$ odwiecznym swoim planem (por. Hi 38,3), by przekonać go, że Jego rządy nad światem są mądre, sprawiedliwe i łaskawe, co uwidacznia się $\mathrm{w}$ trosce o wszystkie stworzenia, a zwłaszcza o człowieka ${ }^{23}$. Autor w tym fragmencie nie zajmuje się historycznym procesem powstawania świata, a strukturę wszechświata nakreślił zgodnie z wyobrażeniami starożytnych mieszkańców Bliskiego Wschodu (por. Hi 38,6), a to oznacza, że chce on przede wszystkim pouczyć o Bogu, który jest jedynym Panem i Stwórcą wszystkiego, co istnieje (Biblia Paulińska).

W starotestamentowych tekstach o charakterze mądrościowym stworzenie mówi o Bogu, świadcząc tym samym o Jego istnieniu. Księga Przysłów w hymnie na cześć Mądrości ukazuje ją jako postać - mistrzynię towarzyszącą stwórczemu działaniu Boga, kiedy powoływał On do istnienia wszechświat (por. Prz 8,22-31) ${ }^{24}$. Podobnie Mądrość Syracha w poemacie zawierającym pochwalną wypowiedź Mądrości - która ,wychodząc z ust Boga" (Syr 24,3), utożsamia się ze słowem Bożym - uwydatnia temat stworzenia Mądrości, jawiącej się jako władczyni świata, przed wszystkim (por. Syr 24). Z kolei autor Księgi Mądrości mówi, że Boga można poznać, rozważając piękno świata stworzonego: „Gdyż na podstawie potęgi i piękna rzeczy stworzonych można przez podobieństwo (gr. analogōs) dojść do kontemplacji ich Stwórcy" (Mdr 13,5). W oparciu o to stwierdzenie można powiedzieć, że racjonalność stworzonego świata nie tylko pozwala człowiekowi odkryć istnienie Boga, który jako niewidzialny Mistrz powołuje do istnienia widzialną rzeczywistość, ale także umożliwia naturalne poznanie Stwórcy pozostającego w relacji do stworzenia ${ }^{25}$.

Myśl o świecie powołanym do istnienia z niczego (łac. productio rei ex nihilo) została wyraźnie sformułowana w greckim tekście Drugiej Księgi Machabejskiej w kontekście męczeńskiej śmierci siedmiu braci oraz ich matki (2 Mch 7). Żydowscy męczennicy, którzy oddają życie podczas prześladowań na tle religijnym w II wieku przed Chr., umierają w przekonaniu, że Bóg im je zwróci. Fundament wiary w zmartwychwstanie został oparty na argumencie, że Bóg, który wszystko stworzył „z niczego” (gr. ouk eks ontōn epoiēsen auta ho theos - dosłownie: ,nie z istniejących rzeczy uczynił je

\footnotetext{
${ }^{22}$ Por. B. Costacurta, Obietnica, dz. cyt., s. 32-33.

${ }^{23}$ Por. A. Tronina, Księga Hioba. Wstęp. Przektad z oryginatu. Komentarz, Częstochowa 2013, s. 608 .

${ }^{24}$ Por. T. Brzegowy, Pisma mądrościowe Starego Testamentu, Tarnów 2007, s. 105.

${ }^{25}$ Por. B. Poniży, Ksiega Madrości. Od egzegezy do teologii, Poznań 2000, s. 169-170.
} 
Bóg”) wskrzesi męczenników: „Proszę cię synu, spójrz na niebo i na ziemię, i na wszystko, co jest na nich. Wiedz, że Bóg uczynił je z niczego i że rodzaj ludzki powstał w ten sam sposób" (2 Mch 7,28). Wypowiedzi skazanych na męczeństwo przepełnia nadzieja życia wiecznego, wypływająca $\mathrm{z}$ wiary w stwórczą wszechmoc Boga, który jako sędzia sprawiedliwy przywróci utracone życie wszystkim, którzy oddają je ze względu na Niego ${ }^{26}$.

Nowy Testament, podejmując tematykę stworzenia, posługuje się greckim terminem ktidzo (,stwarzać”) ${ }^{27}$, przy pomocy którego wyraża czynność Boga Ojca (por. Mt 19,4; Mk 13,19; Rz 1,25), nazywa Boga „Stwórcą” (por. 1 Kor 11,9; Ef 2,10; 3,9; Kol 1,16; $1 \mathrm{Tm} 4,3$; Ap 4,11; 10,6) oraz mówi o działaniu Jezusa w kontekście tajemnicy stworzenia nowego człowieka (por. Ef 2,15; 4,24; Kol 3,10) ${ }^{28}$. Nowotestamentowe wypowiedzi dają wyraz wierze, że wszystko, co istnieje, zostało stworzone przez Boga (por. 1 Kor 8,6; Ef 3,9; Hbr 3,4; Ap 4,11), gdyż, jak podaje Paweł Apostoł w Liście do Kolosan, w Chrystusie - pośredniku w dziele stworzenia i zbawienia - „wszystko zostało stworzone $\mathrm{w}$ niebie i na ziemi: to, co widzialne i niewidzialne" (Kol 1,16; por. Dz 4,24; 14,15; 17,24; Rz 11,36; Ap 10,6; 14,7). Przekazany w tym piśmie chrystologiczny hymn (Kol 1,15-20) sławi Jezusa, który będąc „obrazem Boga niewidzialnego”, „Pierworodnym wobec wszelkiego stworzenia”, „Początkiem” oraz „Pierworodnym spośród umarłych”, pozostaje w wyjątkowej więzi tak ze światem, jak i „nowym stworzeniem”, gdyż ,jest ich pośrednikiem i celem, przez Niego i dla Niego zostało wszystko stworzone i pojednane" 29 .

Teksty Nowego Testamentu posługują się w różnym kontekście sformułowaniami nawiązującymi do „początku” świata. Tego typu aluzje są obecne w takich frazach, jak: „od początku stworzenia” (gr. apo de archēs ktiseōs; Mk 10,6; 13,19; Mt 24,21; 2 P 3,4), czy ,przed stworzeniem świata” (gr. pro katabolēs kosmou; J 17,24; Ef 1,4; 1 P 1,20). W nowotestamentowych pismach można znaleźć potwierdzenie myśli, że stworzenie dokonało się poprzez słowo Boże. Autor Listu do Hebrajczyków pisze: „Przez wiarę poznajemy, że światy zostały stworzone słowem Bożym, czyli to, co widzimy, nie powstało z rzeczy widzialnych" (Hbr 11,3). Apostoł Paweł nazywa swoje powołanie powtórzeniem początku stworzenia, gdyż Bóg, który powiedział: „«Z ciemności zajaśnieje światłość», zajaśniał w naszych sercach, aby zabłysło poznanie chwały Bożej, która jest na obliczu Jezusa Chrystusa"

\footnotetext{
${ }^{26}$ Por. S. Gądecki, Walka i męczeństwo za wiarę (2 Księga Machabejska), w: Wprowadzenie $w$ myśl $i$ wezwanie ksiąg biblijnych. Księgi historyczne Starego Testamentu, red. J. Frankowska, t. 3, Warszawa 2007, s. 289-290.

${ }^{27}$ Por. J. T. Nelis, A. Schoors, Création, w: Le Dictionnaire Encyclopédique de la Bible, red. J. Bajard, M. Defossez, J. Longton, R.F. Poswick, G. Rainotte, wyd. III, Turnhout 2002, s. 319.

${ }^{28}$ Por. R. Popowski, Wielki stownik grecko-polski Nowego Testamentu, Warszawa 1997, s. $350-351$.

${ }^{29}$ J. Gnilka, Teologia Nowego Testamentu, tłum. W. Szymona OP, Kraków 2002, s. 424.
} 
(2 Kor 4,6), a to stało się istotną prawdą dla przemiany Pawła: „Jeśli ktoś jest w Chrystusie, jest nowym stworzeniem. To, co dawne, przeminęło, a nastało nowe" $(2 \text { Kor } 5,17)^{30}$.

Ewangelie synoptyczne ukazują Jezusa, który wysławia swojego Ojca jako „Pana nieba i ziemi”, nawiązując w ten sposób do wiary w Boga Stwórcę (por. Mt 11,25; Łk 10,21), natomiast ewangelista Jan widzi w Chrystusie Logos, Słowo Boga, przez które wszystko zaistniało (por. J 1,1-3). Pierwsze słowa Janowego tekstu o Logosie: „Na początku było Słowo” (J 1,1) są aluzją do podniosłego sformułowania otwierającego Księgę Rodzaju: „Na początku Bóg stworzył niebo i ziemię" (Rdz 1,1). Rozpoczynająca Ewangelię Jana fraza $(\mathrm{J} 1,1)$ odnosi się nie tylko do początku stworzenia, ale wskazuje także na preegzystencję Logosu, który jako Pośrednik stworzenia miał udział w stwarzaniu wszystkiego, co istnieje (por. $\mathrm{J} 1,3)^{31}$.

W tekstach Nowego Testamentu pojawia się również tematyka nowego stworzenia (por. 2 Kor 5,17; Ga 6,15; Ef 2,10.15; 4,24; Kol 3,10; 2 P 3,13; Ap 21,1). Obecne stworzenie, które „woła i cierpi” z powodu „zepsucia, które je zniewala", pragnie odnowienia (por. Rz 8,19-25) ${ }^{32}$, czekając aż nadejdzie pełnia królestwa Bożego, kiedy to Bóg zamieszka pośród swojego stworzenia (Ap 21,1-8), pozwalając się ujrzeć takim, jakim jest ${ }^{33}$.

${ }^{30}$ Por. J. Becker, Paul. Apostle to the Gentiles, thum. O.C. Dean Jr, Louisville (Kentucky) 1993, s. 77.

${ }^{31}$ Por. J. Gnilka, Teologia Nowego Testamentu, dz. cyt., s. 305.

${ }^{32}$ Por. J.T. Nelis, A. Schoors, Création, dz. cyt., s. 319.

${ }^{33}$ Por. P. Prigent, L'Apocalypse, Paris 2008, s. 203. 